\title{
Antibacterial Activity of the Essential Oil of Rosemary Pepper
}

\author{
Kelvi Wilson Evaristo Miranda ${ }^{1}$, Elisabeth Mary Cunha da Silva ${ }^{1}$ and Terezinha Feitosa Machado*2 \\ ${ }^{1}$ Department of food engineering at the Federal University of Ceará, Brazil \\ ${ }^{2}$ Embrapa Agroindústria Tropical, Fortaleza, CE, Brazil
}

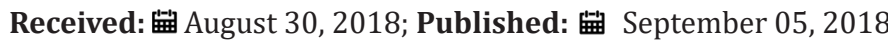

*Corresponding author: Terezinha Feitosa Machado, Embrapa Agroindústria Tropical, Fortaleza, CE, Brazil

\begin{abstract}
In this study, it was evaluated the antimicrobial activity of essential oil of rosemary pepper (Lippia sidoides). To determine this activity, six bacterial species related to spoilage and foodborne disease, Listeria monocytogenes, L. innocua, Staphylococcus aureus, Escherichia coli, Pseudomonas aeruginosa and Salmonella choleraesuis, were used. The agar diffusion method was employed. The results showed that the essential oil of rosemary pepper has antibacterial activity against all species studied. Therefore, the oil can be considered a natural alternative for use in food preservation.
\end{abstract}

Keywords: Essential Oil; Antibacterial Activity; Food Preservation

\section{Introduction}

Several pathogens still represent a public health problem in developed and developing countries. Salmonella spp., Clostridium perfringens, Campylobacter, Listeria monocytogenes, Vibrio parahaemolyticus, Bacillus cereus and enteropathogenic Escherichia coli, cause more than $90 \%$ of cases of food poisoning [1]. In addition, Staphylococcus aureus, which is responsible for the most frequent food poisoning, is acquiring a new epidemiological dimension due to methicillin-resistant strains [2]. The extensive use of antimicrobials has driven growing resistance among bacterial species and the effectiveness of these compounds have declined seriously [3-5]. Thus, due to increasing pressure from consumers and legal authorities, food processors, researchers and regulatory agencies are showing interest in natural products with bactericidal activity. Rosemary pepper (Lippia sidoides Cham) is a shrub native to the semi-arid region of northeastern Brazil, which was introduced in governmental phytotherapy programs in several northeastern states, due to its use in the region's popular medicine practices [6].

The chemical constituents and pharmacological properties of Rosemary pepper essential oil have been disclosed as results of successive studies in the areas of dentistry and cosmetology [7-8]. In addition to the antimicrobial property, which justifies the therapeutic application of the plant, the oil also has larvicidal activity for Aedes aegypti, a mosquito that transmits dengue and molluscicide on Biomphalaria glabrata, a vector of schistosomiasis
[9-10]. Considering the effectiveness of oil essential of rosemary pepper against some human pathogens, this paper are presented information about the antimicrobial activity of oil against some foodborne pathogenic bacteria in order to develop strategies for future applications as a bio-agent in foods. The essential oil used in this study was kindly provided by Prof. Dr. Renato Innecco, from Department of Plant Science at the Federal University of Ceará. The oil was obtained from leaves of the rosemary pepper, extracted by the steam distillation method. After extraction the oil was added with anhydrous sodium sulfate to absorb possible water molecules. The dried oil was transferred to an amber glass jar with screw cap and stored in a cool place without the incidence of light [11].

The antimicrobial activity of the essential oil was determined by agar diffusion method described by the National Committee for Clinical Laboratory Standards [12], modified, using agar wells for the application of the different concentrations of oil, instead of using paper disks impregnated with the samples. The antimicrobial activity was assessed by the diameter of the growth inhibition zone (IZ)of Escherichia coli ATCC 10536, Listeria monocytogenes ATCC 7644, Pseudomonas aeruginosa ATCC 9027, Staphylococcus aureus ATCC 25923 and Salmonella Typhimurium ATCC 51812. Zone of inhibition with diameters equal to or greater than $7 \mathrm{~mm}$ were considered indicative of microbial sensitivity to oil. The results showed that rosemary pepper essential oil has antibacterial activity against all species studied. L. monocytogenes was the most 
oil sensitive species ( $\mathrm{IZ}=48.5 \pm 0.7 \mathrm{~mm}$ ), followed by P. aeruginosa $(\mathrm{IZ}=44.0 \pm 1.4 \mathrm{~mm}), \mathrm{S}$. aureus $(42.5 \pm 0 \mathrm{~mm}), 7 \mathrm{~mm})$, E. coli $(41.5$ $\pm 0.7 \mathrm{~mm})$ and $\mathrm{S}$. Tiphymurium $(39.5 \pm 0.7 \mathrm{~mm})$. This suggests that the oil can be considered a suitable alternative to chemical additives for use in the food industry, since security needs and satisfies consumer demand for natural components.

\section{References}

1. Healy B, Cooney S, O Brien S, Iversen C, Whyte P, et al. (2010) Cronobacter (Enterobacter sakazakii): an opportunistic foodborne pathogen. Foodborne Pathog Dis 7(4): 339-335.

2. Harrison EM, Paterson GK, Holden MT, Larsen J, Stegger M, et al. (2013) Whole genome sequencing identifies zoonotic transmission of MRSA isolates with the novel mecA homologue mecC. Embo Molecular Medicine 5(4): 509-515.

3. Micele A, Aleo A, Corona O, Sardina MT, Mammina C, et al. (2014) Anticabterial activity of Borago officinalis and Brassica juncea aqueous extracts evaluated in vitro and in situ using different food model systems. Food Control 40: 157-164.

4. Lai S, Tremblay J, Déziel E (2009) Swarming motility: a multicellular behavior conferring antimicrobial resistance. Environ Microbio 11(1): 126-136.

ISSN: 2574-1241

DOI: 10.26717/BJSTR.2018.08.001698

Terezinha Feitosa Machado. Biomed J Sci \& Tech Res

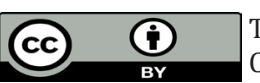

This work is licensed under Creative Commons Attribution 4.0 License

Submission Link: https://biomedres.us/submit-manuscript.php
5. (2010) Scenihr - Scientific Committee on Emerging and Newly Identified Health Risks, Research strategy to address the knowledge gaps on the antimicrobial resistance effects of biocides.

6. (2002) Matos FJA Farmácias vivas: sistema de utilização de plantas medicinais projetado para pequenas comunidades. Fortaleza: UFC p. 267.

7. Botelho MA, Nogueira NA, Bastos GM, Fonseca SG, Lemos TL, et al. (2007) Antimicrobial activity of the essential oil from Lippia sidoides, carvacrol and thymol gainst oral pathogens. Braz J Med Biol Res 40(3): 349-356.

8. Costa AS, Arrigoni Blank MF, Blank AF, Mendonça AB, Amâncio VF, et al. (2007) Horticultura Brasileira. Estabelecimento de alecrim-pimenta in vitro 25(1): 68-72.

9. Carvalho AF, Melo VM, Craveiro AA, Machado MI, Bantim MB, et al. (2003) Larvicidal activity of the essential oil from Lippia sidoides Cham. Against Aedes aegypti Linn. Mem Inst Oswaldo Cruz 98(4): 569-571.

10. Matos FJA, Oliveira F (1998) Lippia sidoides Cham. - farmacognosia, química e farmacologia. Revista Brasileira de Farmacognosia 79: 84-87.

11. Craveiro AA, Matos FJA, Alencar JWA (1976) A simple and inexpensive steam generator for essential oils extraction. Journal of Chemical Education 53(10): 652.

12. Wayne (2003) National Committee for Clinical Laboratory Standards. Performance standards for antimicrobial disk susceptibility tests: approved standards 8. (Document M2-A8).

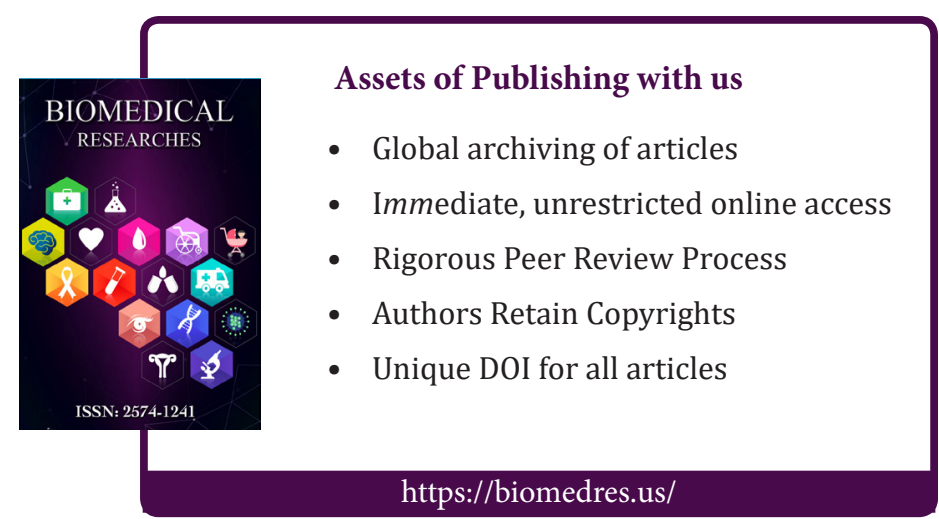

